\title{
The Cartography OF \\ The Northwest Coast of America \\ TO THE YEAR I8OO
}





\section{The Cartography of the \\ Northwest Coast of America \\ To the Year I800}

HENRY R. WAGNER

IN TWO VOLUMES

$\overline{\text { Volume I }}$

UNIVERSITY OF CALIFORNIA PRESS

Berkeley, California

1937 


\section{University of California Press \\ Berkeley, California}

\section{Cambridge University Press}

London, England

Copyright, 1937, by the

Regents of The University of California

PRINTED IN THE UNITED STATES OF AMERICA 